\title{
KAJIAN PERSEPSI KONSUMEN TERHADAP USAHA NASI KUNING SAROJA DI KOTA MANADO
}

\author{
Nur Hijriyana Jusuf \\ Leonardus R. Rengkung \\ Ribka M. Kumaat
}

\begin{abstract}
This study aims to identify the consumer perception of "Nasi Kuning Saroja" from aspects of price, taste, service, cleanliness, packaging and color. This study was conducted for 2 months by taking 70 respondents. The sampling process is conducted by purposive sampling. The results showed that the "Nasi Kuning Saroja" has advantages in several aspects such as color, cleanliness, packaging, service and taste. While the price aspect is categorized as expensive.*Ir**
\end{abstract}

Keywords: consumer perception, yellow rice saroja, Manado City.

\begin{abstract}
ABSTRAK
Penelitian ini bertujuan untuk mengidentifikasi bagaimana persepsi konsumen terhadap usaha nasi kuning Saroja dilihat dari aspek harga, rasa, pelayanan, kebersihan, kemasan dan warna. Penelitian ini dilakukan selama 2 bulan dengan jumlah sampel 70 yang menjadi target sampel. Proses pengambilan sampel dilakukan secara purposive sampling. Hasil penelitian menunjukan bahwa usaha nasi kuning Saroja memiliki keunggulan dalam beberapa aspek seperti warna, kebersihan, kemasan, pelayanan dan rasa. Sedangkan aspek harga dikategorikan mahal. *Irr*.
\end{abstract}

Kata kunci: persepsi konsumen, nasi kuning saroja, Kota Manado.

\section{PENDAHULUAN}

\section{Latar Belakang}

Organisasi terbagi 2 yaitu, organisasi publik dan organisasi bisnis. Organisasi publik adalah organisasi yang ditujukan kepada masyarakat umum yang bertujuan menghasilkan pelayanan kepada masyarakat, tanpa membedakan status dan kedudukannya, dan organisasi bisnis adalah organisasi ditujukan yang menyediakan barang dan jasa tersebut sesuai dengan bisnis pasar (Malayu, 2008). Organisasi bisnis termasuk didalamnya adalah perusahaan yang tujuan utamanya adalah untuk mencari keuntungan.
Keunggulan kompetitif perusahaan tergantung pada beberapa aspek seperti harga, rasa, pelayanan, kebersihan, penampilan dan warna. Aspek-aspek ini digunakan sebagai alat pemasaran untuk mempengaruhi konsumen. Ini berlaku untuk semua usaha termasuk usaha kuliner.

Usaha kuliner merupakan salah satu usaha yang dewasa ini berkembang pesat dan memiliki potensi berkembang yang cukup besar. Sudah banyak pelaku usaha yang meraup untung dari usaha kuliner ini. Namun tidak sedikit pula pelaku usaha kuliner yang gulung tikar alias bangkrut, karena strategi yang digunakan kurang tepat dan harga, rasa, 
pelayanan yang kurang optimal. Artinya keberhasilan sebuah bisnis kuliner dalam memenangkan persaingan ditentukan oleh penerapan strategi yang tepat serta hubungan baik yang dijalani dengan konsumen. Ada beberapa usaha kuliner di Kota Manado yang memiliki potensi yang cukup besar salah satu usaha kuliner yang memiliki potensi yang cukup besar adalah usaha nasi kuning.

Usaha-usaha nasi kuning yang ada di Kota Manado bervariasi mulai dari yang bersakala kecil maupun yang berskala besar. Salah satu usaha nasi kuning yang berskala besar di Kota Manado adalah nasi kuning Saroja. Nasi kuning Saroja memiliki skala yang besar dan mempunyai pesaing yang sejenis. Setiap pengusaha menerapkan strategi yang berbeda guna menarik minat pelanggan. Bagaimanapun juga terdapat persepsi yang berbeda-beda mengenai faktor yang dipertimbangkan dalam keputusan pembelian yang dilakukan oleh konsumen. Schiffman \& Kanuk dalam Njo Anastasia (2013) menyatakan, persepsi adalah hakekatnya merupakan proses psikologis yang kompleks serta melibatkan aspek fisiologi. Proses psikologi dimulai dari adanya aktivitas memilih, mengorganisasi dan menginterpretasi sehingga konsumen mampu memberikan makna atas suatu obyek.

Usaha nasi kuning Saroja menjalankan hubungan yang baik dengan konsumen agar usahanya terus berjalan dengan baik. Alasan konsumen dalam membeli nasi kuning Saroja karena keyakinan konsumen bahwa nasi kuning Saroja memiliki keunggulan kompetitif dibandingkan nasi kuning di tempat lain yang memiliki karekteristik yang sama dengan nasi kuning Saroja dilihat dari berbagai aspek seperti aspek harga, rasa, pelayanan, kebersihan, kemasan dan warna.

\section{Definisi Persepsi}

Persepsi berasal dari kata perception (inggris) yang artinya menerima atau mengambil. Persepsi merupakan salah satu aspek psikologis yang penting bagi manusia dalam mencapai merespon kehadiran berbagai aspek dan gejala di sekitarnya. Menurut Kamus Besar Bahasa Indonesia, persepsi adalah tanggapan (penerimaan) langsung dari sesuatu. Proses seseorang mengetahui beberapa hal melalui panca inderanya.

Schiffman \& Kanuk dalam Njo Anastasia (2013) menyatakan persepsi pada hakekatnya merupakan proses psikologis yang kompleks serta melibatkan aspek fisiologis. Proses psikologis dimulai dari adanya aktivitas memilih, mengorganisasikan dan menginterpretasikan sehingga konsumen mampu memberikan makna atas suatu obyek. Proses persepsi diawali dengan adanya stimuli atau situasi yang sedang dihadapinya yang mengenai panca indra dan disebut sebagai sensasi. Asal stimuli sangat beragam, ada yang berasal dari luar individu atau dari dalam diri individu. Faktor stimuli yang berasal dari luar dapat mem-pengaruhi pilihan konsumen, seperti kekontrasan atau perbedaan yang mencolok, kebaruan, intensitas, besarnya ukuran obyek, gerakan dan pengulangan. Faktor stimuli tersebut akan menarik perhatian konsumen sehingga secara perlahan masuk dalam benak atau pikiran konsumen. Faktor stimuli yang berasal dari dalam adalah pengharapan dan motivasi.

Slameto (2003) mengungkapkan bahwa persepsi adalah proses yang menyangkut masuknya pesan dan informasi di dalam otak manusia. Informasi dan pesan yang diterima tersebut muncul dalam bentuk stimulus yang merangsang otak untuk meengolah lebih lanjut yang kemudian mempengaruhi seseorang dalam berperilaku.

Setiap orang mempunyai kecenderungan dalam melihat benda yang sama dengan cara yang berbeda-beda. Perbedaan tersebut bisa dipengaruhi oleh banyak faktor, diantaranya adalah pengetahuan, pengalaman dan sudut pandangnya. Persepsi juga bertautan dengan cara pandang seseorang terhadap suatu objek tertentu dengan cara yang berbeda-beda dengan menggunakan alat indera yang dimiliki, kemudian berusaha untuk menafsirkannya. Persepsi baik positif maupun negatif ibarat file yang sudah tersimpan rapi di dalam alam 
pikiran bawah sadar kita. File itu akan segera muncul ketika ada stimulus yang memicunya, ada kejadian yang membukanya. Persepsi merupakan hasil kerja otak dalam memahami atau menilai suatu hal yang terjadi di sekitarnya (Waidi, 2006).

Dari penjelasan di atas dapat ditarik suatu kesamaan pendapat bahwa persepsi merupakan suatu proses yang dimulai dari penglihatan hingga terbentuk tanggapan yang terjadi dalam diri individu sehingga individu sadar akan segala sesuatu dalam lingkungannya melalui indera-indera yang dimilikinya.

\section{Definisi Keunggulan Kompetitif}

Menurut Porter dalam Fajriyan (2013), keunggulan kompetitif adalah kemampuan perusahaan untuk memformulasi strategi pencapaian peluang profit melalui maksimisasi penerimaan dari investasi yang dilakukan. Sekurang-kurangnya ada dua prinsip pokok yang perlu dimiliki perusahaan untuk meraih keunggulan kompetitif yaitu adanya nilai pandang pelanggan dan keunikan produk. Keunggulan kompetitif dalam kewirausahaan adalah adanya inovasi, kreatifitas dan ide.

Winarno (2011), mengatakan bahwa yang menjadi pembeda antara pengusaha dan wirausaha adalah adanya keinginan wirausaha untuk mengambil tantangan guna lebih memajukan lagi usaha yang dirintisnya. Dalam kewirausahaan keunggulan kompetitif berupa inovasi, kreatifitas dan ide sangatlah penting. Karena keunggulan kompetitif tersebut, seorang wirausaha dapat memunculkan usaha - usaha baru. Usaha baru yang dimaksud disini bukanlah usaha yang semata- mata baru atau belum terdapat pesaing. Namun juga dapat berarti usaha dengan pasar atau target yang baru.

Keunggulan bersaing menurut Porter (2008), adalah kemampuan suatu perusahaan untuk meraih keuntungan ekonomis di atas laba yang mampu diraih oleh pesaing di pasar dalam industri yang sama. Perusahaan yang memiliki keunggulan kompetitif senantiasa memiliki kemampuan dalam memahami perubahan struktur pasar dan mampu memilih strategi pemasaran yang efektif. Pilihan tiap-tiap perusahaan terhadap strategi generik di atas akan bergantung kepada analisis lingkungan usaha untuk menentukan peluang dan ancaman. Berdasarkan studi yang dilakukan oleh Porter, beberapa cara untuk memperoleh keunggulan bersaing antara lain dengan menawarkan produk atau jasa dengan harga minimum (cost leadership), menawarkan produk atau jasa dengan yang memiliki keunikan dibanding pesaingnya (differentiation), atau memfokuskan diri pada segmen tertentu (focus).

Perusahaan yang tidak mempunyai daya saing akan ditinggalkan oleh pasar. Karena tidak memiliki daya saing berarti tidak memiliki keunggulan, dan tidak unggul berarti tidak ada alasan bagi suatu perusahaan untuk tetap survive di dalam pasar persaingan untuk jangka panjang. Daya saing berhubungan dengan bagaimana efektivitas suatu organisasi di pasar persaingan, dibandingkan dengan organisasi lainnya yang menawarkan produk atau jasa-jasa yang sama atau sejenis.

Perusahaan-perusahaan yang mampu menghasilkan produk atau jasa yang berkualitas baik adalah perusahaan yang efektif dalam arti akan mampu bersaing. Porter (2008), mengatakan : " competition is at the core of the success or failure of firms. Persaingan adalah inti dari kesuksesan atau kegagalan perusahaan. Terdapat dua sisi yang ditimbulkan oleh persaingan, yaitu sisi kesuksesan karena mendorong perusahaanperusahaan untuk lebih dinamis dan bersaing dalam menghasilkan produk serta memberikan layanan terbaik bagi pasarnya, sehingga persaingan dianggapnya sebagai peluang yang memotivasi. Sedangkan sisi lainnya adalah kegagalan karena akan memperlemah perusahaan-perusahaan yang bersifat statis, takut akan persaingan dan tidak mampu menghasilkan produk-produk yang berkualitas, sehingga persaingan merupakan ancaman bagi perusahaannya. Menurut 
kasmir dan Jakfar (2012), daya saing operasi merupakan fungsi operasi yang tidak saja berorientasi ke dalam (internal) tetapi juga keluar (eksternal), yakni merespon pasar sasaran usahanya dengan proaktif.

Keunggulan bersaing merupakan strategi keuntungan dari perusahaan yang melakukan kerjasama untuk berkompetisi lebih efektif dalam pasar. Strategi yang didesain bertujuan untuk mencapai keunggulan bersaing yang terus menerus agar perusahaan dapat terus menjadi pemimpin pasar (Barney dalam Chyntia, 2014). perusahaan mengalami keunggulan bersaing ketika tindakan-tindakan dalam suatu industri atau pasar menciptakan nilai ekonomi dan ketika beberapa perusahaan yang bersaing terlibat dalam tindakan serupa.

Keunggulan bersaing dianggap sebagai keuntungan dibanding kompetitor yang diperoleh dengan menawarkan nilai lebih pada konsumen dibanding penawaran competitor. Keunggulan bersaing diharapkan mampu untuk mencapai laba sesuai rencana, meningkatkan pangsa pasar, meningkatkan kepuasan pelanggan, serta melanjutkan kelangsungan hidup suatu usaha.

\section{Rumusan Masalah}

Usaha kuliner merupakan salah satu usaha yang memiliki potensi berkembang yang cukup besar salah satunya usaha nasi kuning. Keberhasilan sebuah bisnis kuliner dalam memenangkan persaingan ditentukan oleh penerapan strategi yang tepat serta hubungan baik yang dijalani dengan konsumen. Nasi kuning Saroja dapat bersaing dengan pesaing sejenis dan memepertahankan keunggulan kompetitifnya dinilai dari persepsi konsumen.

Berdasarkan uraian diatas rumusan masalah dalam penelitian ini adalah mengidentifikasi bagaimana persepsi konsumen terhadap usaha nasi kuning Saroja dilihat berdasarkan variabel-variabel yang digunakan dalam usaha nasi kuning seperti harga, rasa, pelayanan, kebersihan, penampilan/kemasan dan warna.

\section{Tujuan Penelitian}

Penelitian ini bertujuan untuk mengkaji persepsi konsumen terhadap nasi kuning Saroja berdasarkan harga, rasa, pelayanan, kebersihan, penampilan/kemasan dan warna.

\section{Manfaat Penelitian}

Manfaat penelitian ini diharapkan menjadi bahan informasi kepada pemilik usaha nasi kuning Saroja agar mampu mempertahankan kualitas produk.

\section{METODOLOGI PENELITIAN}

\section{Waktu dan Tempat Penelitian}

Penelitian ini dilaksanakan selama 2 bulan yaitu dari bulan Januari 2018 sampai dengan bulan Maret 2018. Penelitian dilakukan di Rumah Makan Nasi Kuning Saroja yang beralamat di Jl. Diponegoro.

\section{Metode Pengumpulan Data}

Data yang digunakan dalam penelitian ini berbentuk data primer yang berkaitan dengan harga, rasa, pelayanan, kebersihan, penampilan/kemasan dan warna. Metode pengumpulan data dilakukan dengan cara menanyakan langsung kepada para pengunjung Nasi Kuning Saroja dengan menggunakan daftar pertanyaan.

\section{Metode Pengambilan Sampel}

Populasi dalam penelitian ini adalah para pengunjung di Rumah Makan Nasi Kuning Saroja yang makan di tempat. Kategori utama populasi dalam penelitian ini adalah semua pengunjung baik yang sering makan di RM Nasi Kuning Saroja dan di Rumah Makan Nasi Kuning lainnya dengan karakteristik yang sama dengan RM Nasi Kuning Saroja.

Proses pengambilan sampel dilakukan secara purposive sampling dengan jumlah 70 orang/pengunjung sebagai sampel. Proses pengambilan sampel dilakukan selama 1 minggu, yang dimulai dari hari Senin sampai Minggu. Setiap sehari diambil 10 orang/pengunjung yang terdiri dari 3 
orang/pengunjung pada pagi hari, 3 orang/pengunjung pada siang hari, 2 orang/pengunjung pada sore hari dan 2 orang/pengunjung pada malam hari.

\section{Konsep Pengukuran Variabel}

Variabel-variabel yang digunakan dalam penelitian ini adalah:

- Harga

- Rasa

- Pelayanan

Kebersihan

- Kemasan/Penampilan

- Warna

\section{Analisis Data}

Analisis data dalam penelitian dilakukan secara deskriptif dimulai dengan menyusun, mentabulasi, dan mengelompok-kan data serta menghitung persentase dari semua variabel yang diukur berdasarkan skala Likert dengan jenjang 1 sampai 5.

$1=$ Sangat Tidak Setuju/STS

$2=$ Tidak Setuju/TS

$3=$ Netral

$4=$ Setuju/S

$5=$ Sangat Setuju/S

\section{HASIL DAN PEMBAHASAN}

\section{Deskripsi Umum Wilayah Penelitian}

\section{Deskripsi Usaha Nasi Kuning Saroja}

Nasi kuning Saroja merupakan salah satu usaha kuliner yang didirikan oleh pasangan suami istri alm H Abubakar dan alm Hj Salma Simen pada tahun 1977. Usaha ini mulai beroperasi di Jalan Diponegoro Kelurahan Lawangirung Kecamatan Wenang dan sampai saat ini usaha ini masih berlokasi di tempat tersebut. Nasi kuning Saroja dibuka setiap harinya dari pukul 5.30 WITA sampai dengan pukul 21.00 WITA.

\section{Ruang Lingkup Bidang Usaha}

Nasi kuning Saroja merupakan usaha yang bergerak dalam bidang kuliner Tempat pembuatan nasi kuning berada bersama dengan tempat produksi nasi kuningnya. Harga yang diterapkan di nasi kuning Saroja per bungkus seharga Rp. 20.000.

\section{Sebarang Sampel}

Tujuan untuk mendapatkan populasi adalah untuk mendapatkan responden yang bisa membandingkan kondisi antara nasi kuning Saroja dan lainnya. Tabel 1 berikut menunjukan sebarang responden sebagai populasi dan sampel di rumah makan nasi kuning Saroja.

\begin{tabular}{lcccccccc} 
Tabel l. Sebarang Konsumen \\
\hline Sampel & \multicolumn{7}{c}{ Hari } & Jumlah \\
\cline { 2 - 7 } & Senin & Selasa & Rabu & Kamis & Jumat & Sabtu & Minggu & \\
Target Sampel & 10 & 10 & 10 & 10 & 10 & 10 & 10 & 70 \\
Non Target & 6 & 12 & 5 & 8 & 7 & 9 & 11 & 58 \\
Sampel & & & & & & & & \\
\hline Jumlah & 16 & 22 & 15 & 18 & 17 & 19 & 21 & 128 \\
\hline Sumber: Pengolahan Data Primer, 2018 & & & & &
\end{tabular}

\section{Karakteristik Responden}

\section{Jenis Kelamin Responden}

Perbedaan jenis kelamin dapat menjadi pembeda bagi seseorang dalam melakukan pembelian nasi kuning karena pada umumnya seseorang memilih nasi kuning karena penyajiannya yang praktis dan mudah didapatkan. Berikut Tabel 2 yang menunjukan jenis kelamin responden yang membeli nasi kuning Saroja.

\begin{tabular}{cccc} 
Tabel & 2. & \multicolumn{2}{c}{$\begin{array}{c}\text { Karakteristik } \\
\text { Berdasarkan Jenis Kelamin }\end{array}$} \\
\hline No & Jenis & Jumlah & $\begin{array}{c}\text { Persentase } \\
(\%)\end{array}$ \\
& Kelamin & Konsumen & 48.57 \\
\hline 1 & laki-laki & 34 & 51.43 \\
2 & Perempuan & 36 & 100.00
\end{tabular}

Sumber: Pengolahan Data Primer, 2018 


\section{Usia Responden}

Responden atau konsumen yang datang ke rumah makan sifatnya beragam mulai dari anak muda sampai dengan orang tua sekalipun, maka hal ini memungkinkan responden bervariasi dalam hal usia. Berikut Tabel 3 yang menunjukan usia responden yang mengkonsumsi nasi kuning Saroja.

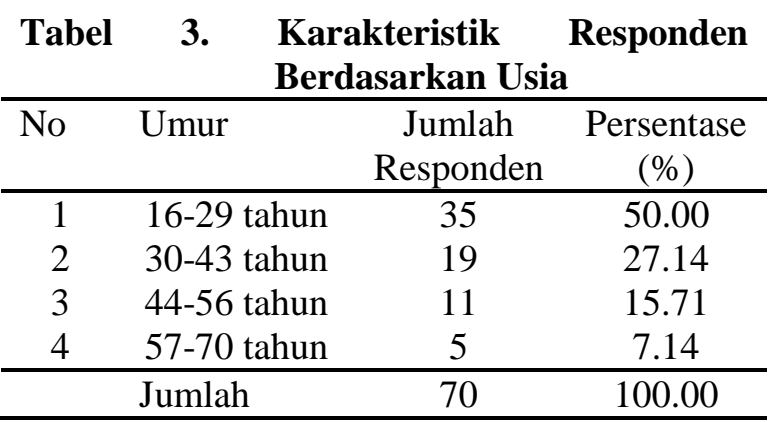

Sumber: Pengolahan Data Primer, 2018

\section{Pekerjaan Responden}

Tingkat pekerjaan juga akan menunjukkan status sosial yang akan mempengaruhi seseorang dalam pengambilan keputusan dalam pembelian. Pada penelitian ini, sebagian besar responden mengelompokkan pada jenis pekerjaan Swasta. Secara lengkap bisa dilihat pada Tabel 4 .

\begin{tabular}{clcc} 
Tabel 4. & $\begin{array}{c}\text { Karakteristik } \\
\text { Berdasarkan }\end{array}$ & $\begin{array}{c}\text { Responden } \\
\text { Pekerjaan }\end{array}$ \\
\hline No & Pekerjaan & Jumlah & Persentase $(\%)$ \\
\hline 1 & Swasta & 20 & 28.57 \\
2 & ASN & 8 & 11.43 \\
3 & Driver & 5 & 7.14 \\
4 & Perawat & 3 & 4.29 \\
5 & Mahasiswa & 16 & 22.86 \\
6 & Pekerja Sosial & 2 & 2.86 \\
7 & Wiraswasta & 5 & 7.14 \\
8 & IRT & 2 & 2.86 \\
9 & Pedagang & 3 & 4.29 \\
10 & Pensiunan & 2 & 2.86 \\
& Perangkat & & \\
11 & Desa & 1 & 1.43 \\
12 & E.O & 1 & 1.43 \\
13 & Kontraktor & 1 & 1.43 \\
14 & Fotografer & 1 & 1.43 \\
\hline \multicolumn{2}{l}{ Jumlah } & 70 & 100.00 \\
\hline
\end{tabular}

Sumber: Pengolahan Data Primer. 2018

\section{Asal Daerah Responden}

Asal daerah responden dapat mempengaruhi keberhasilan usaha dimana daerah tersebut dapat menjadi area pemasaran atau menjadi tempat penjualan/distribusi. Berikut Tabel 5 yang menunjukan asal daerah konsumen yang membeli nasi kuning Saroja.

\begin{tabular}{|c|c|c|c|}
\hline Tabe & $\begin{array}{l}\mathbf{K} \\
\mathbf{B}\end{array}$ & \multirow{2}{*}{\multicolumn{2}{|c|}{ Berdasarkan Asal Daerah }} \\
\hline No & Asal & & \\
\hline 1 & Kota Manado & 53 & 75.71 \\
\hline 2 & Luar Manado & 17 & 24.29 \\
\hline & Jumlah & 70 & 100.00 \\
\hline
\end{tabular}

Sumber: Pengolahan Data Primer, 2018

\section{Pendidikan Responden}

Pendidikan yang telah dijalani seseorang tentulah tidak sama antara individu satu dengan individu lainnya sehingga menanamkan sebuah pola fikir yang berbeda pula. Dengan pola fikir yang berbeda tentunya dapat mempengaruhi perilaku seseorang dalam melakukan keputusan pembelian. Karakteristik responden berdasarkan pendidikan dapat dilihat pada Tabel 6 berikut.

Tabel 6. Karakteristik Responde Berdasarkan Pendidikan

\begin{tabular}{cccc}
\hline No & Pendidikan & Jumlah & Persentase (\%) \\
\hline 1 & SMP & 2 & 2.86 \\
2 & SMA & 31 & 44.29 \\
3 & Diploma & 5 & 7.14 \\
4 & S1 & 30 & 42.86 \\
5 & S2 & 2 & 2.86 \\
\hline & Jumlah & 70 & 100.00 \\
\hline
\end{tabular}

Sumber: Pengolahan Data Primer, 2018

\section{Persepsi Konsumen}

Persepsi adalah proses yang menyang-kut masuknya pesan dan informasi di dalam otak manusia. Informasi dan pesan yang diterima tersebut muncul dalam bentuk stimulus yang merangsang otak untuk meengolah lebih lanjut yang kemudian mempengaruhi seseorang dalam berperilaku. 
Dalam penelitian ini penilaian konsumen terhadap nasi kuning Saroja dalam mem-pertahankan keunggulan kompetitifnya pada pasar persaingan yang diukur berdasarkan variabel-variabel harga, rasa, pelayanan, kebersihan, kemasan dan warna. Pengukuran variabel-variabel tersebut berdasarkan skala Likert dengan skor 1 sampai 5. Hasil penelitian mengenai keunggulan kompetitif terkait dengan variabel-variabel tersebut dijelaskan sebagai berikut.

\section{Harga}

Tabel 7 menunjukkan bahwa 2 responden $(2.86 \%)$ menyatakan sangat setuju bahwa harga yang ditawarkan oleh rumah makan nasi kuning Saroja dalam kategori murah, dan 18 responden $(25.71 \%)$ menyatakan setuju dengan harga yang murah karena nasi kuning Saroja menawarkan harga yang sesuai dengan apa yang didapatkan. Selanjutnya terdapat 15 responden $(21.43 \%)$ yang memilih netral (tidak dapat menilai) bahwa nasi kuning saroja memiliki harga yang tidak mahal dan tidak murah, karena sesuai dengan daya pembeli. Kemudian 5 responden $(7.14 \%)$ menyatakan tidak setuju bahwa harga yang ditawarkan oleh rumah makan nasi kuning Saroja dalam kategori murah karena tidak sesuai dengan kantong mahasiswa. Kemudian 30 responden $(42.86 \%)$ menyatakan sangat tidak setuju bahwa harga yang ditawarkan oleh rumah makan nasi kuning Saroja adalah murah dibandingkan dengan pesaingnya karenakan brand-nya yang sudah terkenal luas oleh masyarakat lokal maupun daerah lainnya.

Tabel 7. Harga Produk

\begin{tabular}{lcccccc}
\hline & \multicolumn{6}{c}{ SKOR } \\
\cline { 2 - 7 } & $\begin{array}{c}\text { Sangat } \\
\text { Tidak Setuju }\end{array}$ & Tidak Setuju & Netral & Setuju & Sangat Setuju & $\begin{array}{c}\text { Jumlah } \\
\text { Responden }\end{array}$ \\
\hline Jumlah & 30 & 5 & 15 & 18 & 2 & 70 \\
\hline Persentase (\%) & 42.86 & 7.14 & 21.43 & 25.71 & 2.86 & 100 \\
\hline Sumber : Pengolahan Data Primer, 2018 & & & &
\end{tabular}

\section{Rasa}

Tabel 8 menunjukan bahwa menurut 5 responden $(7.14 \%)$ menyatakan sangat setuju bahwa rasa yang ditawarkan oleh nasi kuning Saroja adalah enak dan 20 responden (28.57\%) menyatakan setuju bahwa rasa yang ditawarkan adalah enak. Persepsi enak karena nasi kuning Saroja memiliki rasa yang khas dibandingkan pesaingnya dan memiliki racikan yang cocok dengan lidah. Sedangkan responden yang memilih skor 3 netral (tidak dapat menilai rasa yang ditawarkan oleh nasi kuning Saroja dengan pesaingnya) sebanyak 22 responden $(31.43 \%)$ karena nasi kuning Saroja memiliki rasa yang sama dengan pesaingnya. Terdapat 12 responden yang menyatakan tidak setuju $(30.00 \%)$ dan 2 responden menyatakan sangat tidak setuju $(2.86 \%)$ bahwa nasi kuning Saroja memiliki rasa yang enak karena nasi kuning pesaing lebih enak dibandingkan dengan nasi kuning yang ditawarkan Saroja.

\begin{tabular}{|c|c|c|c|c|c|c|}
\hline & \multicolumn{5}{|c|}{ SKOR } & \\
\hline & 1 & 2 & 3 & 4 & 5 & \\
\hline & $\begin{array}{c}\text { Sangat } \\
\text { Tidak Setuju }\end{array}$ & Tidak Setuju & Netral & Setuju & Sangat Setuju & $\begin{array}{c}\text { Jumlah } \\
\text { Responden }\end{array}$ \\
\hline Jumlah & 2 & 21 & 22 & 20 & 5 & 70 \\
\hline Persentase (\%) & 2.86 & 30.00 & 31.43 & 28.57 & 7.14 & 100 \\
\hline
\end{tabular}

\section{Pelayanan}

Tabel 9 menunjukan bahwa menurut 12 responden $(17.14 \%)$ menyatakan sangat setuju dan 20 responden $(28.57 \%)$ menyataka bahwa pelayanan yang ditawarkan oleh nasi kuning Saroja memuaskan karena penyajian di nasi kuning Saroja cepat dan tepat. Kemudian 14 responden $(20.00 \%)$ memilih netral (tidak mampu menilai pelayanan yang ditawarkan oleh nasi kuning Saroja dengan pesaingnya) karena pelayanan yang ditawarkan oleh nasi kuning Saroja sama memuaskan dengan pelayanan yang ditawarkan oleh pesaingnya. Sedangkan 20 responden $(28.57 \%)$ menyatakan 
tidak setuju dan 4 responden (5.71\%) menyatakan sangat tidak setuju bahwa pelayanan yang ditawarkan oleh nasi kuning Saroja memuaskan, karena pelayanan di rumah makan nasi kuning Saroja tidak ramah dibandingkan dengan pesaingnya.

Tabel9. Pelayanan

\begin{tabular}{lcccccc}
\hline & \multicolumn{6}{c}{ SKOR } \\
\cline { 2 - 7 } & 1 & 2 & 3 & 4 & 5 & \\
\cline { 2 - 7 } & $\begin{array}{c}\text { Sangat } \\
\text { Tidak Setuju }\end{array}$ & Tidak Setuju & Netral & Setuju & Sangat Setuju & $\begin{array}{c}\text { Jumlah } \\
\text { Responden }\end{array}$ \\
\hline Jumlah & 4 & 20 & 14 & 20 & 12 & 70 \\
\hline Persentase (\%) & 5.71 & 28.57 & 20.00 & 28.57 & 17.14 & 100 \\
\hline
\end{tabular}

Sumber : Data Primer, 2018

\section{Kebersihan}

Tabel 10 menunjukan menurut 15 responden $(21.43 \%)$ menyatakan sangat setuju bahwa tempat di nasi kuning Saroja bersih dan 28 responden (40.00\%) menyatakan setuju karena tempatnya yang selalu dibersihkan, nyaman dan tertata rapi. Sedangkan terdapat 19 responden $(27.14 \%)$ memilih netral (tidak dapat menilai) kebersihan di rumah makan nasi kuning Saroja dengan pesaingnya karena kebersihan di rumah makan Saroja sama dengan kebersihan yang ditawarkan oleh pesaing. Kemudian 6 responden $(8.57 \%)$ menyatakan tidak setuju dengan kebersihan yang bersih di rumah makan nasi kuning Saroja dan 2 responden $(2.86 \%)$ menyatakan sangat tidak setuju karena toilet di rumah makan nasi kuning Saroja perlu diperhatikan dan pesaing menawarkan tempat yang lebih bersih dan nyaman dari rumah makan nasi kuning Saroja.

Tabel 10. Kebersihan

\begin{tabular}{lcccccc}
\hline & \multicolumn{6}{c}{ SKOR } \\
\cline { 2 - 7 } & $\begin{array}{c}\text { Sangat } \\
\text { Tidak Setuju }\end{array}$ & Tidak Setuju & Netral & Setuju & Sangat Setuju & $\begin{array}{c}\text { Jumlah } \\
\text { Responden }\end{array}$ \\
\hline Jumlah & 2 & 6 & 19 & 28 & 15 & 70 \\
\hline Persentase (\%) & 2.86 & 8.57 & 27.14 & 40.00 & 21.43 & 100 \\
\hline
\end{tabular}

Sumber : Data Primer, 2018

\section{Kemasan}

Tabel 11 menunjukan bahwa konsumen yang menyatakan sangat setuju sebanyak 17 $(24.29 \%)$ responden dan $23 \quad(30.00 \%)$ responden menyatakan setuju bahwa kemasan di rumah makan nasi kuning Saroja tidak mudah rusak, karena nasi kuning Saroja menggunakan "woka" sebagai kemasannya. Woka yang tahan panas, tidak mengilangkan cita rasanya, dan unik menjadi strategi yang digunakan oleh nasi kuning Saroja dalam mempertahankan konsumennya. Sedangkan 22 responden $(31.43 \%)$ memilih netral (tidak dapat menilai) karena nasi kuning saroja memiliki kemasan yang sama unik dengan pesaingnya. Kemudian $8(11.43 \%)$ responden menyatakan tidak setuju dan 2 (2.86\%) responden karena untuk pengiriman ke luar kota yang membutuhkan waktu yang cukup lama menyebabkan kemasan mudah rusak (robek) sampai ke tangan konsumen.

Tabel ll. Kemasan

\begin{tabular}{|c|c|c|c|c|c|c|}
\hline & \multicolumn{5}{|c|}{ SKOR } & \multirow[b]{3}{*}{$\begin{array}{l}\text { Jumlah } \\
\text { Responden }\end{array}$} \\
\hline & 1 & 2 & 3 & 4 & 5 & \\
\hline & $\begin{array}{c}\text { Sangat } \\
\text { Tidak Setuju }\end{array}$ & Mudah Setuju & Netral & Setuju & Sangat Setuju & \\
\hline Jumlah & 2 & 8 & 22 & 21 & 17 & 70 \\
\hline Persentase (\%) & 2.86 & 11.43 & 31.43 & 30.00 & 24.29 & 100 \\
\hline
\end{tabular}

\section{Warna}

Tabel 12 menunjukan bahwa sebanyak 23 responden $(32.86 \%)$ menyatakan sangat setuju bahwa nasi kuning Saroja memakai bahan pewarna alami dan 27 responden (38.57\%) menyatakan setuju bahwa nasi kuning Saroja memiliki warna yang alami hal ini dikarenakan warna yang terdapat di nasi kuning Saroja memiliki warna kuning alami atau tidak pucat dan bila dicicipi nasi kuning Saroja memakai kunyit yang diparut. Sedangkan 18 responden (25.71\%) memilih netral karena tidak bisa membedakan warna kuning alami (kunyit) dan pewarna buatan. Dan 1 responden (1.43\%) menyatakan tidak setuju dengan warna di rumah makan nasi kuning saroja yang menggunakan 
pewarna alami dan 1 responden (1.43\%) menyatakan sangat tidak setuju dengan penggunaan bahan pewarna alami karena warna yang dimiliki oleh nasi kuning Saroja tidak pekat (ditambahkan bahan pewarna buatan).

Tabel 12. Warna

\begin{tabular}{lcccccc}
\hline & \multicolumn{5}{c}{ SKOR } & \\
\cline { 2 - 6 } & 1 & 2 & 3 & 4 & 5 & \\
\cline { 2 - 6 } & $\begin{array}{c}\text { Sangat } \\
\text { Tidak Setuju }\end{array}$ & Tidak Setuju & Netral & Setuju & Sangat Setuju & $\begin{array}{c}\text { Jumlah } \\
\text { Responden }\end{array}$ \\
\hline Jumlah & 1 & 1 & 18 & 27 & 23 & 70 \\
\hline Persentase (\%) & 1.43 & 1.43 & 25.71 & 38.57 & 32.86 & 100 \\
\hline
\end{tabular}

Sumber : Data Primer, 2018

\section{Rekapitulasi Pengukuran Persepsi Konsumen}

Persepsi Konsumen dalam penelitian ini diukur berdasarkan enam variabel yaitu, harga, rasa, pelayanan, kebersihan, kemasan, dan warna.

\begin{tabular}{|c|c|c|c|c|c|}
\hline No & & 2 & 3 & 4 & Jumlah Respoder \\
\hline 1 & Harga & $\begin{array}{lc}30 & 5 \\
35 & (50.00 \%)\end{array}$ & 15 & $\begin{array}{c}18 \quad 2 \\
20(28.57 \%)\end{array}$ & 70 \\
\hline 2 & Rasa & $\begin{array}{cc}2 & 21 \\
23 & (32.86 \%)\end{array}$ & 22 & ${ }_{25}^{20}(35.71 \%)^{5}$ & 70 \\
\hline 3 & Pelayanan & $\begin{array}{cc}4 & 20 \\
24 & (34.28 \%)\end{array}$ & 14 & $\begin{array}{c}20 \quad 12 \\
32(45.71 \%)\end{array}$ & 70 \\
\hline 4 & Kebersihan & $\begin{array}{lr}2 & 6 \\
8(11.43 \%)\end{array}$ & 19 & $\begin{array}{cc}28 \quad 15 \\
43(61.43 \%)\end{array}$ & 70 \\
\hline 5 & Kemasan & $\begin{array}{cc}2 & 8 \\
10 & (14.29 \%)\end{array}$ & 22 & $\begin{array}{c}21 \quad 17 \\
38(54.29 \%)\end{array}$ & 70 \\
\hline 6 & Wama & $\begin{array}{lr}1 & 1 \\
2(2.86 \%) \\
\end{array}$ & 18 & $\begin{array}{c}27 \quad 23 \\
50(71.43 \%)\end{array}$ & 70 \\
\hline & Total & $\begin{array}{cc}41 & 61 \\
102(24.29 \%)\end{array}$ & $\begin{array}{c}110 \\
110(26.19 \%)\end{array}$ & $\begin{array}{cr}118 \quad 90 \\
208(49.52 \%)\end{array}$ & 420 \\
\hline
\end{tabular}

Berdasarkan Tabel 13 dapat dijelaskan bahwa nasi kuning Saroja lebih unggul dibanndingkan pesaingnya. Dimana terdapat beberapa aspek yang unggul seperti aspek warna (71.4) Kemudian diikuti oleh aspek kebersihan dimana $(61.45 \%)$ memberikan tanggapan positif terhadap kebersihan di rumah makan nasi kuning Saroja. Diikuti oleh aspek kemasan yaitu $(54.29 \%)$ responden menanggapi positif terhadap kemasan di rumah makan nasi kuning Kemudian diikuti oleh aspek pelayanan yaitu $(45.71 \%)$ Setelah aspek pelayanan, diikuti dengan aspek rasa dimana $(35.71 \%)$ menanggapi positif terhadap rasa dirumah makan nasi kuning Saroja. Kemudian diikuti oleh aspek harga $(50.00 \%)$ responden menyatakan bahwa harga di rumah makan nasi kuning Saroja dalam kategori mahal. Hal ini dapat dikatakan bahwa rumah makan nasi kuning Saroja lebih unggul dan dinilai positif oleh konsumen dilihat dari aspek warna, kebersihan, kemasan, pelayanan dan rasa, sedangkan aspek harga dikatakan tidak kompetitif karena penilaian konsumen terhadap harga di rumah makan nasi kuning Saroja dikategorikan mahal.

\section{KESIMPULAN DAN SARAN}

\section{Kesimpulan}

Berdasarkan hasil penelitian ini dapat dijelasakan bahwa usaha nasi kuning Saroja dinilai lebih unggul dari pesaingnya dan dinilai positif oleh konsumen dilihat dari aspek warna, kebersihan, kemasan, pelayanan dan rasa. Sedangkan dari aspek harga dikatakan tidak kompetitif karena responden menyatakan bahwa nasi kuning Saroja adalah mahal.

\section{Saran}

Berdasarkan kesimpulan yang diperoleh dalam penelitian ini, disarankan bagi Nasi Kuning Saroja sebaiknya memperhatikan harga karena banyak responden yang mengatakan bahwa harga di Saroja mahal. Pelayanan lebih dioptimalkan walau banyak responden yang mengatakan puas tapi ada juga yang mengatakan tidak puas karena pelayan tidak ramah. Pengukuran kepuasan akan pelayanan yang diberikan Nasa Kuning Saroja pada masyarakat harus selalu dilakukan untuk mengetahui dan merencanakan strategi yang lebih baik di masa mendatang dan lebih meningkatkan kualitas pelayanannya agar dapat memenuhi keinginan dan kebutuhan konsumen serta untuk meminimalisasikan masalah. 


\section{DAFTAR PUSTAKA}

Chynthia, Vanessa. 2014. Pengaruh Orientasi Kewirausahaan, Inovasi Produk dan Keunggulan Bersaing Terhadap Kinerja Pemasaran Usaha Nasi Kuning di Kota Manado. Jurnal Ekonomi dan Bisnis, Vol. 2, No. 3, Hal. 1214 - 1224.

Erni. 2012. Proses Kewirausahaan, (online), (http://www.ernirismayana.blogspot). 1 juni 2017

Hasibuan, Malayu S. P. 2008. Manajemen Sumber Daya Manusia. Jakarta: PT. Bumi Aksara.

Kasmir dan Jakfar. 2012. Studi Kelayakan Bisnis. (edisirevisi). Jakarta: Kencana.
Njo, Anastasia. 2013. Peta Persepsi Konsumen Terhadap Atribut Rumah Tinggal Di Surabaya. Jurnal JMK Vol 15 No 2 Hal 141 - 152 ISSN 1411 - 1438.Waidi. 2006. Pemahaman dan Teori Persepsi. Remaja Karya. Jakarta.

Porter, Michael E. 2008. Strategi Bersaing. Kharisma Publishing Grup. Tangerang.

Slameto. 2003. Belajar dan Faktor-faktor yang Mempengaruhinya. Rineka Cipta. Jakarta.

Winarno. 2011. Pengembangan Sikap Entrepreneurship dan Intrapreneurship. Indeks. Jakarta. 